\title{
The Effect of Friction Behaviour and Wear Protection Ability of Selected Base Lubricants on Tribo-Pairs Parameters of Machine Components
}

\author{
S. Kopčanováa, M. Kučera ${ }^{a}$, M. Kučerab, M. Kučera ${ }^{b}$, V. Kučerovác \\ a Faculty of Environmental and Manufacturing Technology, Technical University in Zvolen, Študentská 26 Zvolen, \\ Slovak Republic, \\ ${ }^{b}$ Faculty of Engineering, Slovak University of Agriculture in Nitra, Tr. A. Hlinku 2 Nitra, Slovak Republic, \\ ${ }^{c}$ Faculty of Wood Sciences and Technology, Technical University in Zvolen, Ul. T. G. Masaryka 24 Zvolen, Slovak \\ Republic.
}

Keywords:

Friction Coefficient

Wear

Tribological Node

Dynamic Loading

Process Lubricants

Testing Machine

Corresponding author:

Silvia Kopčanová

Technical University in Zvolen,

Faculty of Environmental and

Manufacturing Technology,

Študentská 26 Zvolen, Slovak

Republic

E-mail: kopcanova15@gmail.com

\begin{abstract}
A B S T R A C T
The experimental tests of selected tribo-pair in three loading cycles were compared in this paper. Tests were performed with mineral transmission oil and ecological synthetic ester base oil, which were dropping by Gravity Force through the overhead part of measuring head of the laboratory testing device. The influence of factors (load cycle, lubricant) on the bearing shells and shafts was statistically verified by analysis of variance (ANOVA). The relevant differences between average values of each specimens were defined using Duncan's multiple range test with a p-value of 0.05. Dynamically loaded tribo-pairs showed bigger mass losses and higher friction coefficients compared to the static cycle in conditions of the experiment, regardless of the lubrication method. This effect was even more significant in environment lubricated with mineral oil. Results confirmed that processes of dynamic loading play a significant role in evaluating selected parameters (wear, friction force, friction coefficient) tribological nodes of agricultural, forestry and other industrial machines.
\end{abstract}

(C) 2018 Published by Faculty of Engineering

\section{INTRODUCTION}

Working machines in the forestry and agricultural sectors are constantly exposed to an adverse working environment $[1,2]$. But, in the case of insufficient maintenance of these machines, the impact of the unfavourable environment occurs on their frequent premature failures, which results in their high recovery costs [3-5].
The friction and wear are two important parameters when operating the machines, because according to them is possible observe if machine is working correctly [6-11]. This information can be useful in constructing and improving the machine for example by using a better material for tribological pairs [12-15]. The lubricating oils are the most common medium to reduce the friction and wear in tribological systems. Lubricants are composed 
from mineral oil and different additives. The problem is that their process of production create component harmful to the environment $[16,17]$. This issue has increased the use of environmentally friendly lubricants as an alternative lubricating oil candidate $[18,19]$. In the forestry and agricultural sectors are used environmentally friendly bio-based lubricants. It is way to save fossil resources and decrease negative impact of forestry and agricultural machinery to environment $[20,21]$.

Researchers [22 - 25] investigated the impact of mineral oil and biodegradable oil on the friction and wear of a journal bearings under static loading conditions. Comparative study of these two types of oils showed, that biodegradable synthetic ester oils have better results of wear and lower friction coefficients than conventional mineral oils.

Ozden et al. [26] observed wear of tribo-pair (bearing and bushing) during operations. Three different rotational speeds, three different running times, two different bearing loads, two bearingshaft gaps and three different lubricant pressures were used. The result of this study showed that the average surface roughness of bearing and bushing does not vary with working conditions. The temperature of bearing and sump oil increased with the load. When the clearance was increased slightly the bearing temperature also increased, while the oil temperature decreased, and roughness was reduced. The bearing mass increased at the highest speed of $3000 \mathrm{rpm}$ while the mass of the bushing did not change with speed.

Rusnák et al. [27] and Tóth et al. [28] tested the effect of oil condition on the friction and wear to different materials of shafts and bearing shells which were used in tribological node of agricultural equipment. To examine the friction and wear behaviour of shaft and hub, realistic lubricating oils were used, reference mineral oils and eco-friendly oils of the same viscosity class 46. Test results predicted that better values were obtained by the ecological oils as lubricant. Moreover, authors monitored the wear of the sliding bearing changes in weight loss of the sliding matched-pair, changes in bearing surface roughness in the contact area and changes in cylindricity tolerance.

In another work, Baskar and Sriram [29] described the tribological properties (frictional coefficient, wear behaviour) of chemically modified rapeseed oils and a synthetic mineral oil to prove that chemically modified rapeseed lubricants exhibited better frictional properties.

Durak et al. [30] proved the effect of rapeseed oil as additive to commercial mineral oil to reduce the friction coefficient at higher temperatures.

Wear amounts of cast alloy journal bearings in lubricated sliding condition under static and dynamic load using experimental tester was evaluated by Savaskan et al. [31]. Under static loading conditions, as cast zinc-based alloys showed higher wear resistance than the equivalent heat-treated alloys, but this behaviour was reversed for dynamic loading.

Trivedi et al. [32] evaluated the friction and wear behaviour of cylinder liber and piston ring materials for four stroke engine system. From the commercial lubricants were used SAE10W30, SAE20W40 and SAE20W50 to analyse frictional and wear behaviour. Tests were conducted for constant load at $140 \mathrm{~N}$ for $105 \mathrm{~min}$ and increment load with the range from $20 \mathrm{~N}$ to $140 \mathrm{~N}$ for $105 \mathrm{~min}$. The cylinder liner and piston ring showed high weight loss with incremental load. By comparing the tribological properties of these lubricants, it is cleared that SAE20W40 and SAE20W50 have better performance compare to SAE10W30.

McCarthy et al. [33] compared the influence of three biodegradable oils and three mineral turbine oils in terms of temperature, power loss and minimum film thickness in a test rig specially developed for the purpose of investigating fluid film journal bearing performance. These oils demonstrated lower temperatures a more favourable viscosity distribution along the film at the higher loads and speeds and comparable minimum oil film thickness values to the mineral oil.

Nikolakopoulos et at. [34] presented experiment tests of journal bearing friction for several configurations of load and journal rotational velocity using mineral oil, a synthetic oil and a bio-based lubricant. By compare the three different lubricating oils, the friction coefficient of bio lubricant was lower in the investigated parameter range in comparison to the mineral oil as well as synthetic oil. 
Padgurskas et al. [35] analysed friction properties of rapeseed oils with anti-wear additives. The research was performed with the four-ball friction test device. Tribological tests of wear resistance properties of differentially produced rapeseed oils at the loads of $150 \mathrm{~N}$ and $300 \mathrm{~N}$ showed that refined rapeseed oil has worse wear resistance compared to unrefined oil. On the other hand, refined rapeseed oil with $2 \%$ of special biological anti-wear additives can decrease wear almost twice.

This paper represents the investigation of tribological parameters of friction pairs in interaction with of commercially available mineral oil and eco-friendly oil at different loading cycles. The results experiments can be used for agricultural, forestry and other industrial machines because it can significantly help at maintenance of machines and prolonging their operating life.

\section{EXPERIMENTAL DETAILS}

\subsection{Base Oils}

Typical technical data for two different lubricating oils which were used in the research are presented in Table 1. Mineral transmission oil (MTO) and ecological hydraulic oil (EHO) have been chosen. MTO with viscosity $170 \mathrm{~mm}^{2} \cdot \mathrm{s}^{-1}$ is selected as commonly used gear oil containing oil-based additives to increase the carrying capacity of lubrication film. It is designed for the lubrication of manual transmissions and final drives (except hypoid ones) of the cars and mobile mechanisms exposed to low temperatures [29]. Fuchs Plantohyd EHO is environmentally friendly lubricating oils based on synthetic ester (HEES), rapidly biodegradable acc. to OECD $301 \mathrm{~B}$ (> $60 \%$ ), awarded with the European Ecolabel (EEL), non-water pollutant. Synthetic esters have advantage of higher viscosity indexes, high flash points low pour points, low temperature fluidity, low volatility, high thermal stability and oxidation resistance, as well as good lubricity characteristics. Generally, contains heavy metalfree, toxicologically harmless additives and additive systems and is use in both mobile and stationary systems. He is claiming a growing share of the market and are replacing mineral oilbased hydraulic fluids in numerous areas, particular in the field of mobile hydraulic applications (construction, water resources management, agriculture, forestry). The kinematic viscosity of biodegradable oil based on synthetic ester is lower than commercial mineral oil, but flash point biodegradable oil based on synthetic ester is almost double than commercial mineral oil (Table 1).

Table 1. Data for the oils investigated.

\begin{tabular}{|c|c|c|c|c|}
\hline Lubricants & $\begin{array}{c}\text { Kinematic } \\
\text { viscosity at } \\
\mathbf{4 0}^{\circ} \mathbf{C} \mathbf{~ m m}^{2} \cdot \mathbf{s}^{-1}\end{array}$ & $\begin{array}{c}\text { Kinematic } \\
\text { viscosity at } \\
\mathbf{1 0 0}^{\circ} \mathbf{C} \mathbf{~ m m}^{2} \cdot \mathbf{s}^{-1}\end{array}$ & $\begin{array}{c}\text { Flash } \\
\text { point } \\
{ }^{\circ} \mathbf{C}\end{array}$ & $\begin{array}{c}\text { Pourpoint } \\
{ }^{\circ} \mathbf{C}\end{array}$ \\
\hline MTO & 170 & 15.3 & 195 & -24 \\
\hline EHO & 46 & 9.4 & 300 & -45 \\
\hline
\end{tabular}

\subsection{Sliding joint}

One tribological pair can be verified during one test only, which consist with bearing shell and steel shaft (Fig. 1).

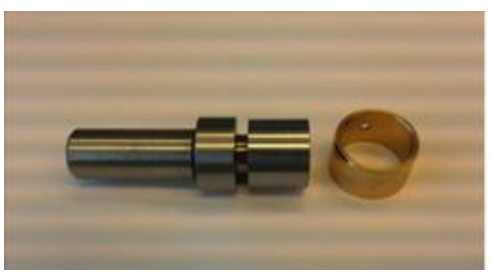

Fig. 1. View of real shaft type and bearing shell before installation in an experimental head.

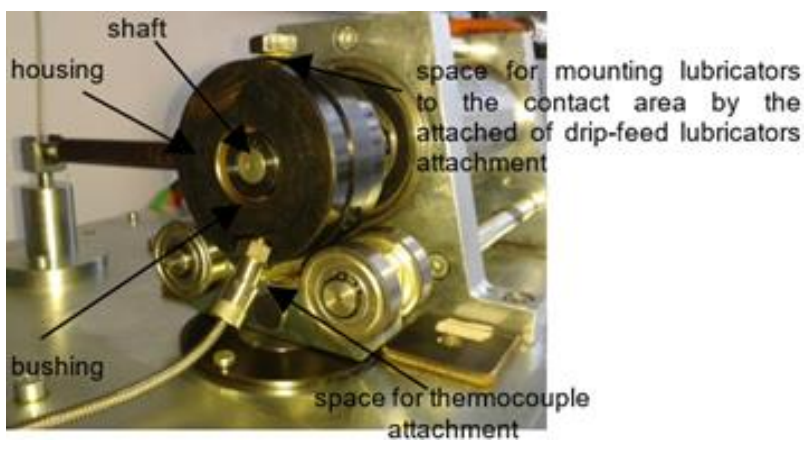

Fig. 2. Sliding pair in the test equipment.

Shaft specimens were $30 \mathrm{~mm}$ in diameter, made of E355 structural steel. The centreline average roughness, $R_{a}$ of shaft specimen surfaces was about $0.4 \mu \mathrm{m}$. The shaft surfaces were processed by polished. The bushing specimens were made from material bronze CuSn 12. Sliding joint in the test equipment is show Fig. 2.

\subsection{Experimental Apparatus}

The experimental tests were conducted using the laboratory device Tribotester M10 
assembled and modernised at Department of Machine Design of the Slovak University of Agriculture in Nitra (Fig. 3). Test equipment can simulate working condition of a sliding knot or perform trial testing of sliding materials at standard dimensions of tested bearings and shafts. It can work at invariable speed and specific load, and variable parameter can be set manually or by the present programme. The experimental device is primarily intended for calculation the friction coefficient in the respective tribo-pair for differently input parameters (load force, load cycle, sliding speed, lubricant), are carried out. The main technical parameters of testing device are given in Table 2 .

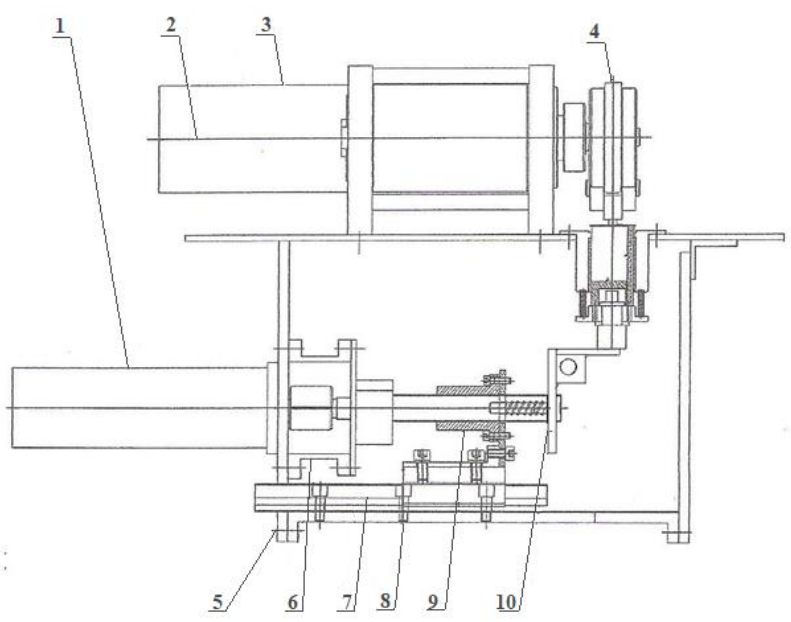

Fig. 3. Measuring experimental test device: 1 - drive motor of module load; 2,3 - motor with head; 4- load head; 5-frame; 6-stowage of the drive motor; 7,8linear rail quid with trolley and touch; 9- ball nut, 10double-lever arm.

Table 2. Specific technical parameters of experimental device Tribotester M10 [4].

\begin{tabular}{|l|c|c|}
\hline \multicolumn{1}{|c|}{ Technical data } & Unit & Value \\
\hline $\begin{array}{l}\text { Dimensions of the gliding } \\
\text { surface of the bushing }\end{array}$ & $\mathrm{mm}$ & $15-30$ \\
\hline Dimensions of the bushing & $\mathrm{mm}$ & max. 35 \\
\hline $\begin{array}{l}\text { Dimensions of the bearing } \\
\text { shell/platelet }\end{array}$ & $\mathrm{mm}$ & $10-30 / 20$ \\
\hline Peripheral speed of the sample & $\mathrm{m} . \mathrm{s}^{-1}$ & $0.05-5$ \\
\hline Loading force & $\mathrm{kN}$ & $0-3$ \\
\hline $\begin{array}{l}\text { Temperature of the friction } \\
\text { couple }\end{array}$ & ${ }^{\circ} \mathrm{C}$ & $20-80$ \\
\hline Frictional moment & $\mathrm{Nm}$ & $0-10$ \\
\hline $\begin{array}{l}\text { Temperature of the operating } \\
\text { environment }\end{array}$ & ${ }^{\circ} \mathrm{C}$ & $20-30$ \\
\hline $\begin{array}{l}\text { Power of the experimental test } \\
\text { device }\end{array}$ & $\mathrm{kW}$ & $\max .1$ \\
\hline
\end{tabular}

The device consists of a base frame with the builtin loading module and drive. In the upper part, there is a headstock with the drive, which provides revolutions of the fixed shaft with the test sample. In the test head, there is fixed type bearing shell as the second element of the friction node. The test head is loaded by loading module with the sensor of a predetermined force. The force is transferring from the friction moment to another force sensor through the test head, from which size of the friction coefficient $\mu$ is determined according to Fig. 4 a by formula (1) by [8]:

$$
\mu=\frac{F \cdot L}{F_{\mathrm{N}} \cdot R}
$$

where:

$$
\begin{aligned}
& F \text { - force at end of measurement head's arm [N] } \\
& L \text {-length of measurement head's arm [mm] } \\
& F_{N} \text { - normal force [N] } \\
& R \text { - radius of the measurement shaft [mm] }
\end{aligned}
$$

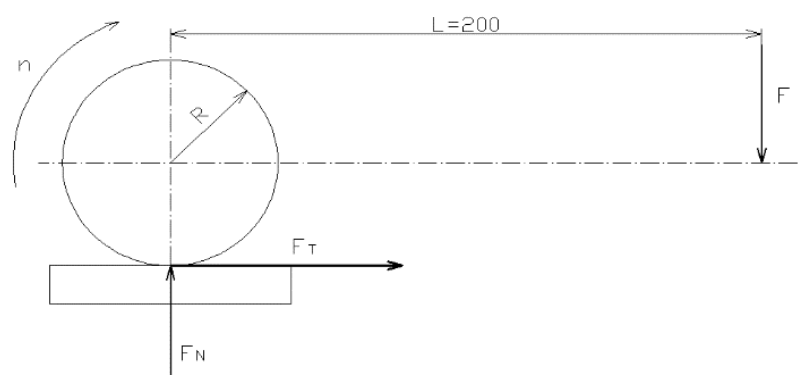

Fig. 4. The principal schema of force relation for evaluation of friction coefficient.

Tribological pairs which were selected for the analysis according to the methodology in three loading regimes with two different lubricants. In the tables and figures are showed the important values of 10 measured values for each loading cycle and each lubrication method. Every test lasted five minutes, where were used Equal conditions (constant load), because was necessary to ensure the stable state of tribopairs friction. The testing beginning automatically after the run-up period and it was recorded by the control system. Accuracy of experimental measurement was $0.1 \%$.

\subsection{Simulation of stochastic processes of loading for the need of own experiment}

For the purpose of experiment, we simulated and statistical processed two stochastic processes with the software created on the department. One was created in the program system MATHEMATICA 5.0 (labelled as no. 1) Fig. 5 and 
the second one in the system Mathcad 11 (labelled as no. 2) Fig. 6.

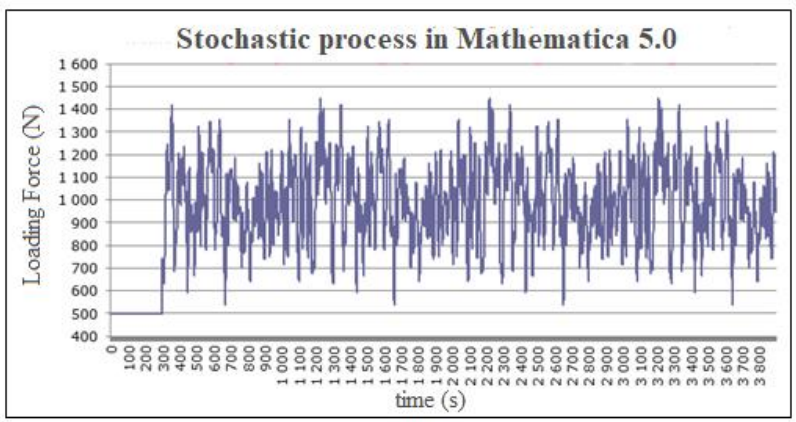

Fig. 5. Continuance of the loading force during dynamic loading, signal no. 1.

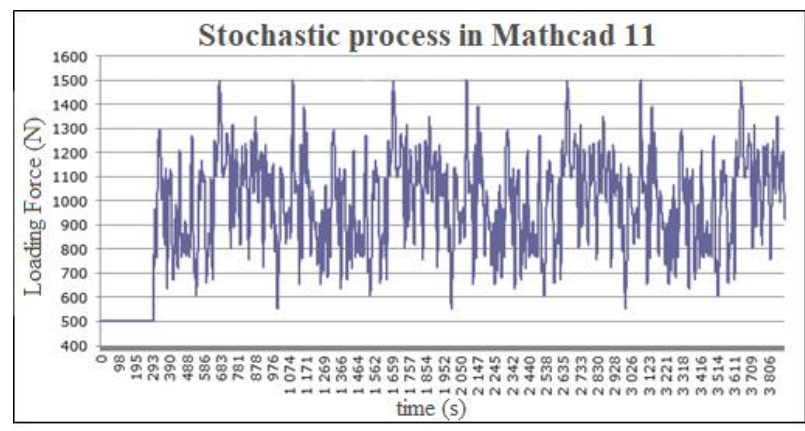

Fig. 6 Continuance of the loading force during dynamic loading, signal no. 1.

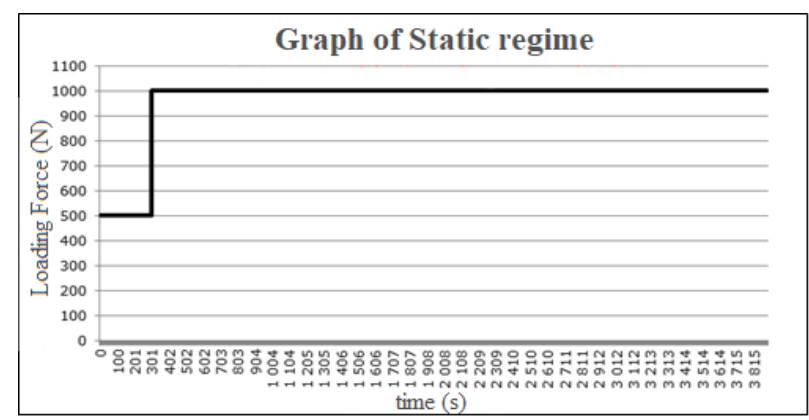

Fig. 7. Continuance of the loading force during static loading.

After the experiment, the main components were evaluated within the correlation theory of stochastic processes. Performing of the Fisher test, the statistical significance of the individual frequencies has been established. The continuances of the periodogram, spectral power density and correlation function were determined. The tests of stationarity showed that both processes are stationary in the average value as well as in the variance Fig. 7. After application of the Fisher test, we found out that there are 16 statistically significant frequencies in power spectrum of the process no. 1 and they occur in the interval $0.10-4.9 \mathrm{~Hz}$ and 15 statistically significant frequencies in power spectrum of the process no. 2 which occur in the interval $0.1-4.3 \mathrm{~Hz}$. The most significant result of regime frequency no. 1 was $3.5296 \mathrm{~Hz}$ and of the process no. 2 was $0.1008 \mathrm{~Hz}$. The continuances of the smoothed signals were used during the loading as two dynamic loading regimes with the average value equivalent to the value of static loading and it is $1000 \mathrm{~N}$. Typical attributes of the loading cycles are showed in Table 3.

Table 3. Parameters of the test and loading regimes.

\begin{tabular}{|l|l|}
\hline $\begin{array}{l}\text { Dynamic } \\
\text { load D1 }\end{array}$ & $\begin{array}{l}\text { stochastic process no. 1 created in system } \\
\text { MATEMATICA; } \\
\text { the average value force 1000 N }\end{array}$ \\
\hline $\begin{array}{l}\text { Dynamic } \\
\text { load D2 }\end{array}$ & $\begin{array}{l}\text { stochastic process no. } 2 \text { created in system } \\
\text { Mathcad 11; the average value force } 1000 \mathrm{~N}\end{array}$ \\
\hline Static load ST & constant value force1000 N \\
\hline $\begin{array}{l}\text { Shaft } \\
\text { rotations }\end{array}$ & $180 \mathrm{~min}^{-1}$ \\
\hline $\begin{array}{l}\text { Duration of } \\
\text { the test }\end{array}$ & 1 hour \\
\hline $\begin{array}{l}\text { Duration of } \\
\text { start }\end{array}$ & $300 \mathrm{~s}$. by load force $500 \mathrm{~N}$ \\
\hline $\begin{array}{l}\text { Way of } \\
\text { lubrication }\end{array}$ & $\begin{array}{l}\text { by force of gravity through the overhead } \\
\text { part of measuring head (500 mm) }\end{array}$ \\
\hline
\end{tabular}

\section{RESULTS AND DISCUSSION}

\subsection{Evaluation of mass loss of shafts and bearing shells for individual loading regimes}

Weight loss is characteristic for wear on tribopairs material in experiment. Wear can be expressed as mass loss in gram. For every measurement was used new tribo-pair. The wear of materials was observed using the laboratory scales Voyager ${ }^{\circledR}$ Pro with an accuracy of $0.001 \mathrm{~g}$. To achieve accurate results was weighting performed in the same and stable environment. The relative amount of the wear correlates with the effectiveness of the lubricant.

For statistically evaluating of the factors influence (load regime, lubricant) on the mass losses of bearing shells (Fig. 6) and shafts (Fig. 7) was used ANOVA. Duncan`s multiple range test was used for specifying significant differences between average values with a $p$ value of 0.05 . The interpretation of results is quite clear in terms of the effect of loading regime on the size of wear under experimental conditions. 
Table 4. Duncan's multiple range test $\mathrm{p}$-values for bearing shells.

\begin{tabular}{|c|c|c|c|c|c|c|c|}
\hline $\begin{array}{c}\text { Loading } \\
\text { regime }\end{array}$ & & ST & ST & D1 & D1 & D2 & D2 \\
\hline & $\begin{array}{c}\text { Type } \\
\text { Oil }\end{array}$ & MTO & EHO & MTO & EHO & MTO & EHO \\
\hline ST & MTO & & 0.001 & 0.049 & 0.036 & 0.000 & 0.268 \\
\hline ST & EHO & 0.001 & & 0.000 & 0.158 & 0.000 & 0.017 \\
\hline D1 & MTO & 0.049 & 0.000 & & 0.000 & 0.001 & 0.004 \\
\hline D1 & EHO & 0.036 & 0.158 & 0.000 & & 0.000 & 0.258 \\
\hline D2 & MTO & 0.000 & 0.000 & 0.001 & 0.000 & & 0.000 \\
\hline D2 & EHO & 0.268 & 0.017 & 0.004 & 0.258 & 0.000 & \\
\hline
\end{tabular}

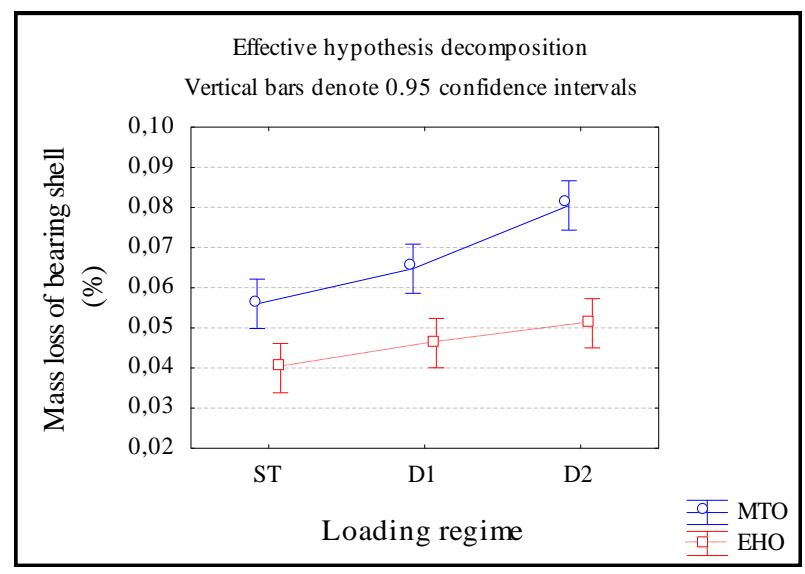

Fig. 8. Influence of loading regime on size of mass loss of bearing shells.

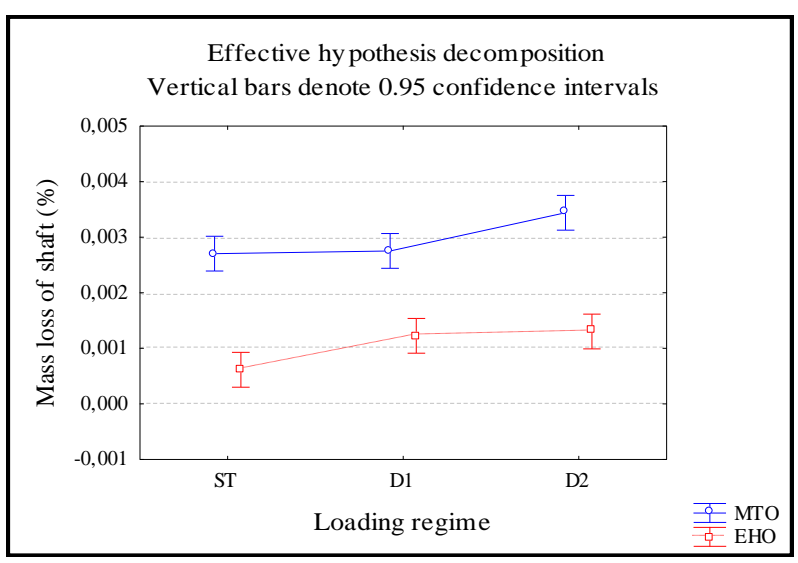

Fig. 9. Influence of loading regime on size of mass loss of shafts.

Duncan's multiple range test $\mathrm{p}$-values (Tables 4 and 5) present the same results, as can be seen from Figs. 8 and 9.

In bearing shell samples, the insignificant changes in mass loss were observed between ecological oil in the static loading regime and ecological oil in the dynamic loading regime D1, and between samples ecological oil in the dynamical loading regime D1 and ecological oil in the dynamical loading regime D2. The other changes of mass loss of bearing shell in the mineral and ecological oil for static and dynamical loading regime D1 and D2 were significant.

Table 5. Duncan's multiple range test $\mathrm{p}$-values for shafts.

\begin{tabular}{|c|c|c|c|c|c|c|c|}
\hline $\begin{array}{c}\text { Loading } \\
\text { regime }\end{array}$ & & ST & ST & D1 & D1 & D2 & D2 \\
\hline & $\begin{array}{c}\text { Type } \\
\text { oil }\end{array}$ & MTO & EHO & MTO & EHO & MTO & EHO \\
\hline ST & MTO & & 0.000 & 0.826 & 0.000 & 0.002 & 0.000 \\
\hline ST & EHO & 0.000 & & 0.000 & 0.008 & 0.000 & 0.004 \\
\hline D1 & MTO & 0.826 & 0.000 & & 0.000 & 0.003 & 0.000 \\
\hline D1 & EHO & 0.000 & 0.008 & 0.000 & & 0.000 & 0.735 \\
\hline D2 & MTO & 0.002 & 0.000 & 0.003 & 0.000 & & 0.000 \\
\hline D2 & EHO & 0.000 & 0.004 & 0.000 & 0.735 & 0.000 & \\
\hline
\end{tabular}

In shaft samples, the insignificant changes in mass loss were observed between mineral oil in the static loading regime and mineral oil in the dynamic loading cycle D1, and between samples ecological oil in the dynamical loading cycle D1 and ecological oil in the dynamical loading regime D2. The other changes of mass loss of shaft in the mineral and ecological oil for static and dynamical loading regime D1 and D2 were significant.

\subsection{The results of the evaluation of friction coefficient changes for individual loading regimes}

Recorded results are processed as graphic continuances of the change of friction coefficient value in dependence on time for individual loading regime and type of lubrication. Individual continuances represent average values of recorded friction coefficients after the statistical processing with the statement of confidence interval. In Figs. 10 and 11, there are continuances of the friction coefficient during static loading. From the presented figures we can state, that there are evident lower values of friction coefficient when was using ecological oil than in case when was using the mineral oil. Also, its steadier continuance may be stated. When lubricating with ecological oil, it falls continually from the value 0.075 to the final value about 0.06 . When lubricating with mineral oil, its initial value is about 0.092 and the final value is 0.07 . From the initially stable continuance it begins to fall rapidly in the time about $1500 \mathrm{~s}$ and its character is less stable. 


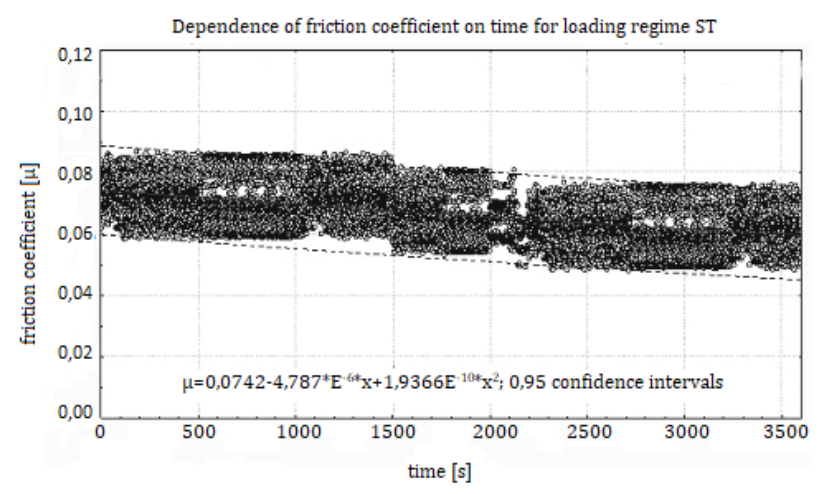

Fig. 10. Friction coefficient vs. time for static loading regime of ecological oil.

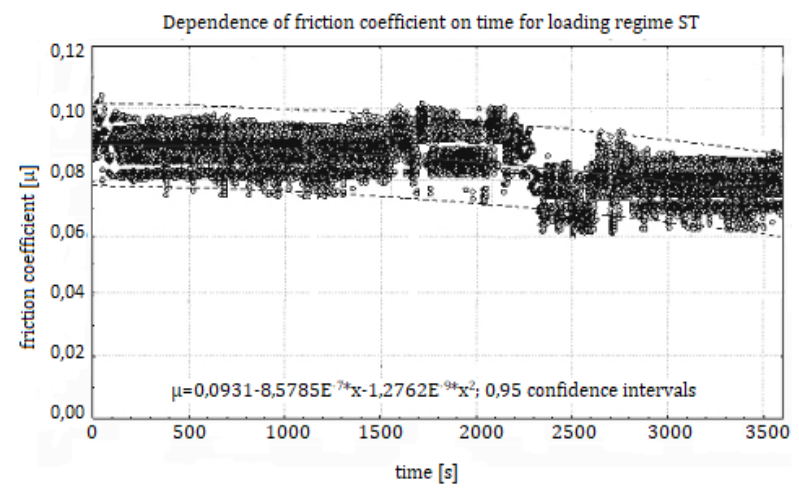

Fig. 11. Friction coefficient vs. time for static loading regime of mineral oil.

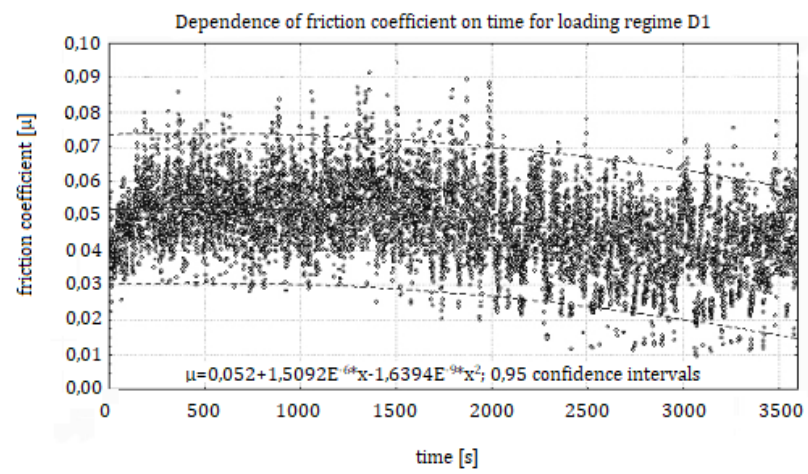

Fig. 12. Friction coefficient vs. time for dynamic loading regime D1 of mineral oil.

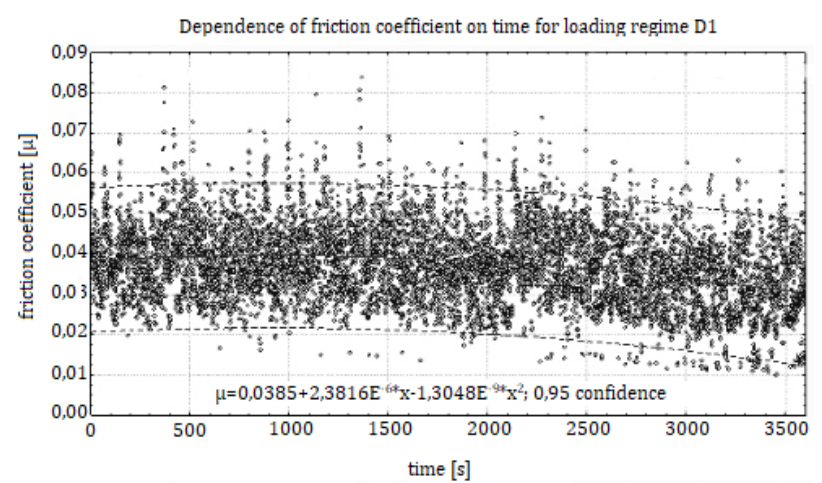

Fig. 13. Friction coefficient vs. time for dynamic loading regime D1 of ecological oil.

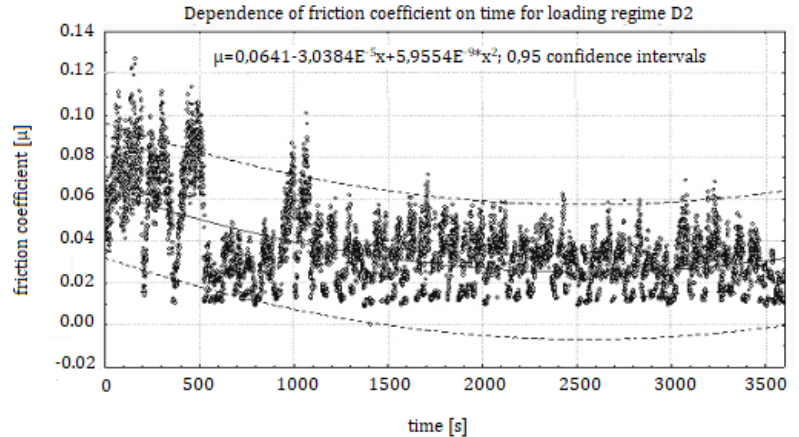

Fig. 14. Friction coefficient vs. time for dynamic loading regime D2 of mineral oil.

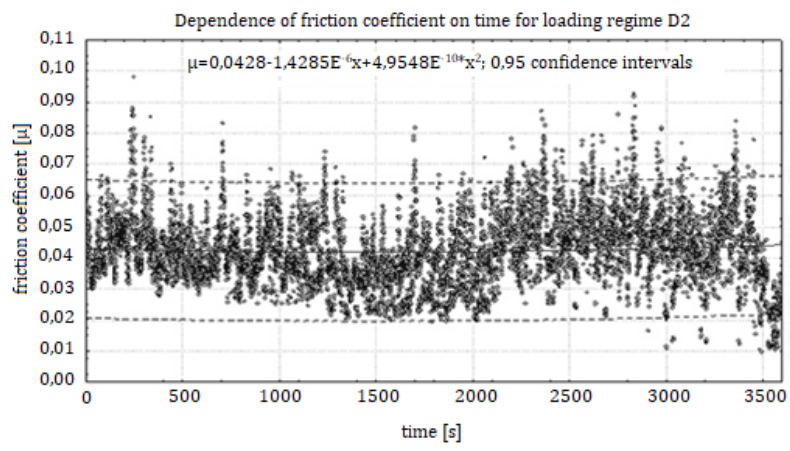

Fig. 15. Friction coefficient vs. time for dynamic loading regime D2 of ecological oil.

In Figures from 12 to 15 there are depicted continuances of the friction coefficient for dynamic loading regimes. Variance of the friction coefficient values is, from the obvious reasons, essentially bigger than in the static loading. In case of loading D1 and ecological oil, the average values of the friction coefficient increases gently at the beginning from the value 0.038 and next, in time $1500 \mathrm{~s}$, gentle fall to the final value 0.03 follows. When lubricating with mineral oil, the coefficient continually falls from the value 0.052 to the value about 0.04 . In case of loading D2 with lubrication of ecological oil, it has rarely balanced continuance (Fig. 13). Its value is about 0.042 . When lubricating with mineral oil it falls sharply from the initial value 0.065 to the final value of 0.035 ; it has the lowest value in time of the test $2500 \mathrm{~s}$ and it is 0.03 . The average values of the friction coefficients show lower values, more stable continuance and lower dispersion when lubricating with the ecological oil.

\subsection{The results of the evaluation of worn surface for individual loading regimes}

Surfaces of the bearing shells and the shafts were submitted under the microscope for 
further analysis of the wear process during the experiment. After thorough cleaning, there were separated segments from the bearing shells so that inner cylindrical part (Fig. 16) could be observed. Surfaces of the shafts were examined without any modifications, because outer cylindrical surfaces were concerned. Chosen couple pairs and every loading regime were submitted to examination. Photography of the chosen pair couples shown in Figs. 17 and 18 represent characteristic surfaces for individual loading regimes and lubrication types.

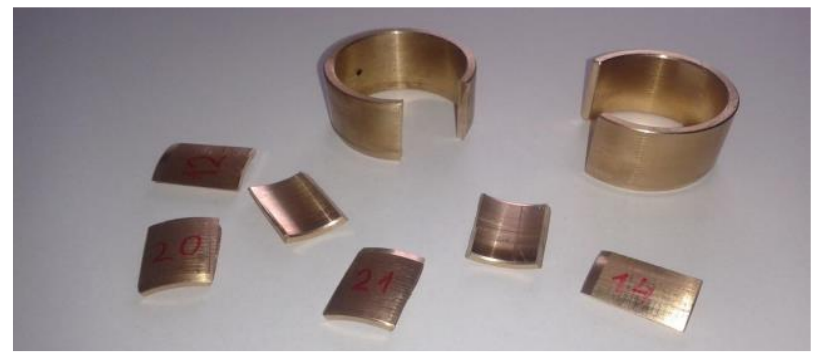

Fig. 16. Inner cylindrical part of the cut bearing shell.

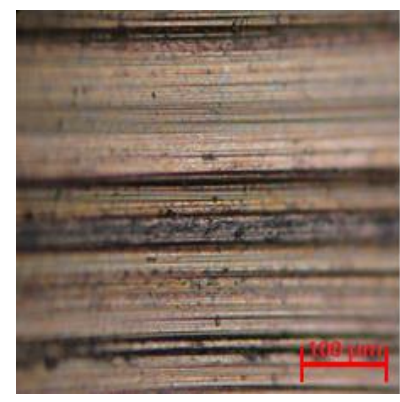

(a)

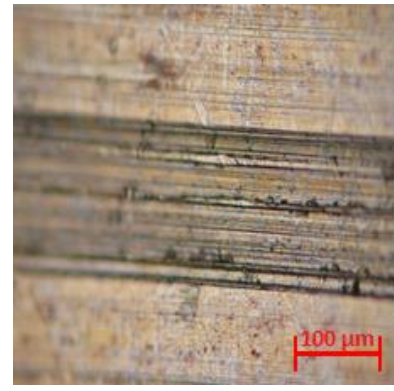

(c)

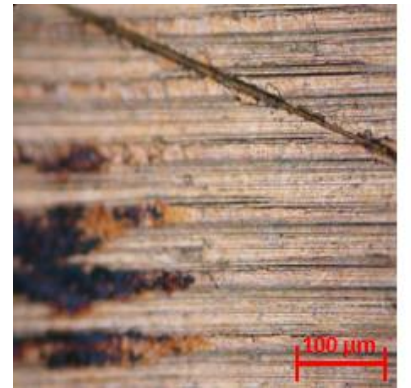

(e)

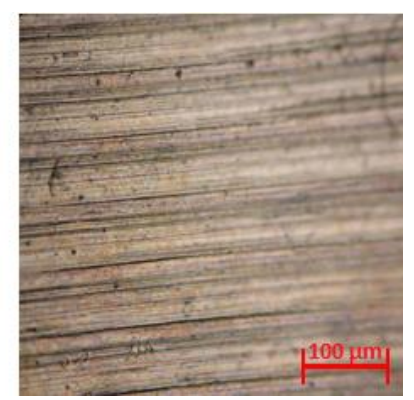

(b)

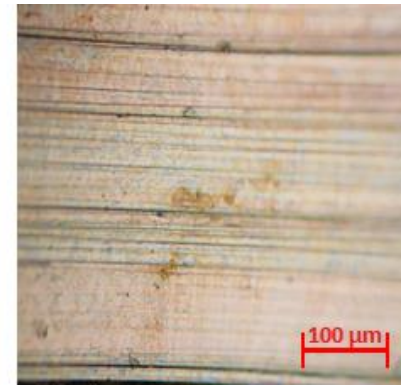

(d)

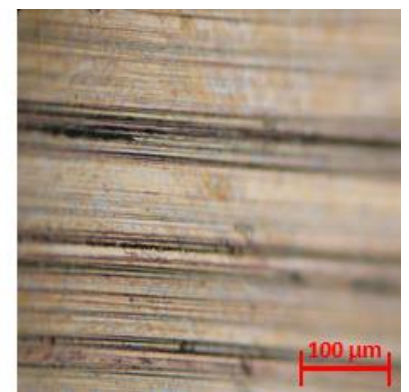

(f)
Fig. 17. (a) Surface of the bearing shell after static loading lubricated by mineral oil; (b) Surface of the bearing shell after static loading, lubricated by ecological; (c) Surface of the bearing shell after D1 loading lubricated by mineral oil; (d) Surface of the bearing shell after D1 loading, lubricated by ecological oil; (e) Surface of the bearing shell after D2 loading lubricated by mineral oil; (f) Surface of the bearing shell after D2 loading, lubricated by ecological oil.

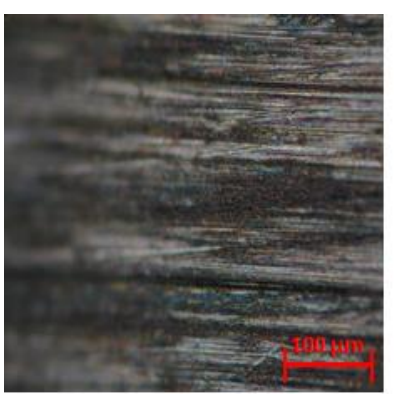

(a)

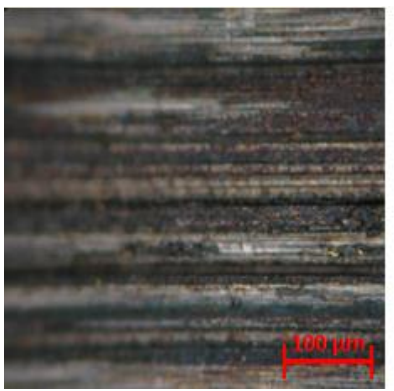

(c)

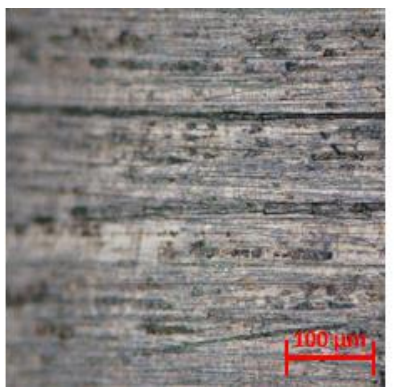

(e)

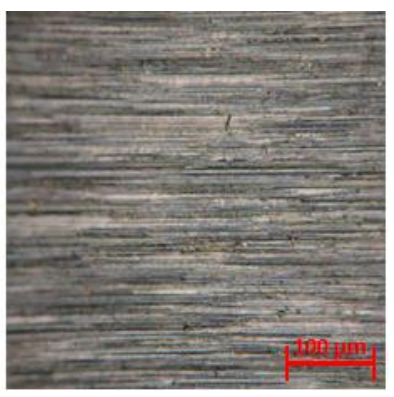

(b)

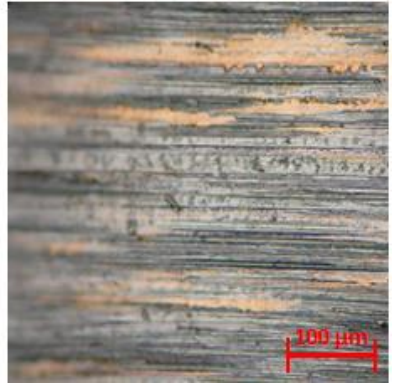

(d)

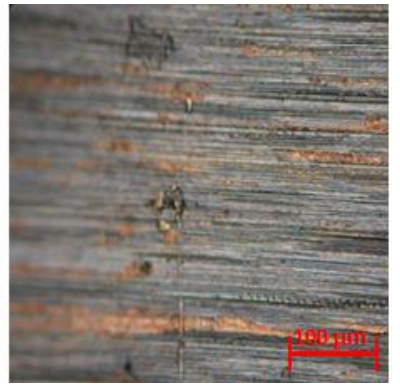

(f)
Fig. 18. (a) Surface of the shaft after ST loading by lubricated by mineral oil; (b) Surface of the shaft after ST loading, lubricated by ecological oil; (c) Surface of the shaft after D1 loading by lubricated by mineral oil; (d) Surface of the shaft after D1 loading, lubricated by ecological oil; (e) Surface of the shaft after D1 loading by lubricated by mineral oil; (f) Surface of the shaft after D1 loading, lubricated by ecological oil.

Pursuant to examination of worn surfaces in Figs. 17 and 18 and the results of the weight losses of the friction couple elements, we can state for individual loading regimes as follows:

- in case of worn bearing shells in the environment lubricated with mineral oil, there are visible significant marks of the 
wear compared to ecological oil, regardless the loading regime,

- in case of worn shaft, which weight losses are essentially lower and when lubricating with ecological oil (Figs. 18b, 18d and 18f), amount of the transferred material from the bearing shell to the surface of the shaft after multiple plastic deformation is visible,

- in case of dynamic loading regime, there is longitudinal groove more significant, especially when lubricating with mineral oil.

Groove caused by released rotational particles probably from the hard metal across the longitudinal groove can be seen in Fig. 18e. Similar signs of the wear are visible also in Fig. $17 \mathrm{f}$, but they are not so significant, and they can be observed at dynamic loading regimes.

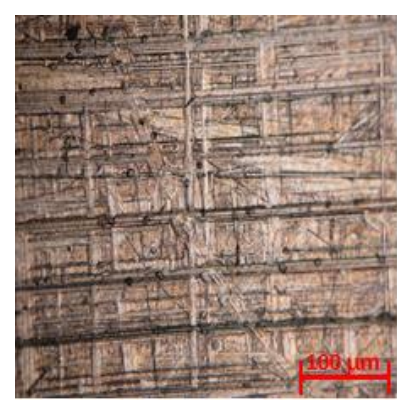

(a)

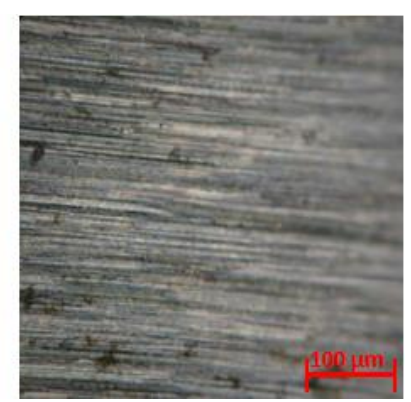

(b)
Fig. 19. (a) Surface of the bearing shell before loading; (b) Surface of the shaft before loading.

Characteristic relief of the bearing shell and the shaft surfaces before the experiment is shown in Fig. 19.

\section{CONCLUSION}

This study has proved the effect of selected lubricants on the tribological pairs at various loading regimes: steel shaft/bronze bushing, which consists to:

- Tests were performed under the same operating conditions at an ambient temperature of $21^{\circ} \mathrm{C}$ and each test lasted 1 hour.

- Dynamically loaded specimens showed higher mass losses compared to the static load in conditions in all experiments. This effect was even more significant in environment lubricated with mineral oil.
- According the Duncan's test the significant impact on monitored parameters have dynamic stochastic process D2 created in the Mathcad 11 system and with oil based on petroleum.

- The average values of the friction coefficients in case of lubrication with ecological oil show lower values.

- Higher values of friction coefficients were observed in dynamic loading regimes compared to static load as found out, as there is a rapid change in real contact force in dynamic modes

- In case of evaluation of shafts and bushings surfaces it can be stated that by lubrication with mineral oil there are more visible traces of wear than ecological oil lubrication irrespective of the way of loading.

- The interpretation of measured data using statistical methods showed the evident effect of dynamic loading regimes as well as the type of oil on the specified parameters of tribological pairs in mechanical components of machines.

Also results of relevant co-workers [37-43] reported that mineral based oils have worst results of wear and higher values of frictional coefficient like than bio-based oils.

\section{Acknowledgments}

Experiments were carried out under the project support science and research VEGA 1/0227/15 Study of tribological characteristics of the new high hard coatings on materials suitable for gearings and project IPA 11/2018 Multiparametric diagnostics of manufacturing machines in technical practice.

\section{REFERENCES}

[1] R. Majdan, R. Abraham, M. Kučera, P. Haas, Analysis of the Effect of Loading Process on Tribological System Properties, Acta Universitatis Agriculturae et Silviculturae Mendelianae Brunensis, vol. 64, iss. 3, pp. 825833, 2016, doi: 10.11118 /actaun201664030825 
[2] M. Walczak, J. Caban, A. Marczuk, Evaluation of tribological properties of polymer materials used for sliding bearings in agricultural machinery, Agricultural Engineering, vol. 21, iss. 1, pp. 95103, 2017, doi: 10.1515/agriceng-2017-0010

[3] A. Kelemesh, 0. Gorbenko, A. Dudnikov, I. Dudnikov, Research wear resistance of bronze bushings during plastic vibration deformation, Eastern-European Journal of Enterprise Technologies, vol. 2, no. 11, pp. 16-20, 2017, doi: 10.15587/1729-4061.2017.97534

[4] F. Tóth, P. Haas, J. Rusnák, M. Kadnár, Experimental comparison of the tribological properties of selected surfaces created by thermal spraying technology, Acta Universitatis Agriculturae et Silviculturae Mendelianae Brunensis, vol. 64, iss. 3, pp. 893-899, 2016, doi.org/10.11118/actaun201664030893

[5] B. Bhushan, Modern Tribology Handbook: Principles of Tribology, vol. 1, CRC Press, 2001.

[6] P. Sedlak, B. Bialobrzeska, T. Stawicki, Friction coefficient and wear resistance of a modified polypropyleneegnated with different oils, Iranian Polymer Journal, vol. 25, iss. 3, pp. 263-275, 2016, doi: 10.1007/s13726-016-0419-7

[7] D. Nilsson, B. Prakash, Static/dynamic friction and wear of some selected polymer materials for conformal tribo-pairs under boundary conditions, Friction vol. 1, iss. 3, pp. 232-241, 2013, doi: 10.1007/s40544-013-0020-4

[8] M. Kadnár, J. Kadnár, S. Hloch, J. Valíček, J. Rusnák, The design and verification of experimental machine for real journal bearing testing, Tehnički vjesnik, vol. 18, no. 1, pp. 95-98, 2011.

[9] P.L. Menezesa, Kishore, S.V. Kailas, M.R. Lovell, Friction and transfer layer formation in polymersteel tribo-system: Role of surface texture and roughness parameters, Wear 271, iss. 9-10, 2 pp. 213-2221, 2011, doi: 10.1016/j.wear.2010.12.047

[10] P. Beňo, J. Marienčík, J. Turis, D. Kozak, P. Konjatic, The friction factor dependence on the load and revolutions in sliding bearings without relubrication, Tehnički vjesnik vol. 23 , no. 4, pp. 997-1001 2016, doi: 10.17559/TV20140908114234

[11] S. Bair, P. Šperka, I. Křupka, M. Hart, Quantitative elastohydrodynamic film thickness of mechanically degraded oil, Tribology International, vol. 65, pp. 33-38, 2013, doi: 10.1016/j.triboint.2013.02.032

[12] A. Adebogun, R. Hudson, A.Breakspear, C. Warrens, A. Gholinia, A. Matthews, P. Withers, Industial gear oils: Tribological performance and subsurface changes, Tribology Letters, vol. 66:65, pp. 1-13, 2018, doi: 10.1007/s11249-018-1013-2
[13] S. Baskar, G. Sriram, S. Arumugam, Tribological Analysis of a Hydrodynamic Journal Bearing under the Influence of Synthetic and Biolubricants, Tribology Transaction, vol. 60, iss. 3, pp. 428-436, 2017, doi: 10.1080/10402004.2016.1176285

[14] G. Biresaw, J.C. Lansing, G.B. Bantchev, R.E. Murray, R.E. Harry-O'Kuru, Chemical, Physical and Tribological Investigation of Polymercaptanized Soybean Oil, Tribology Letters, vol. 65:87, pp. 1-16, 2017, doi: 10.1007/s11249-017-0866-0

[15] S. Lawate, Environmentally-friendly hydraulic fluids, in S.Z. Erhan, J.M. Perez (Ed.): Bio-based Industrial Fluids and Lubricants, pp. 35-45, AOCS Press, Champaign, IL, 2002.

[16] A. Ruggiero, R. D’Amato, M. Merola, P. Valášek, M. Müller, Tribological characterization of vegetal lubricants: Comparative experimental investigation on Jatropha curcas L. oil, Rapessed Methyl Ester oil, Hydrotreated Rapeseed oil, Tribology International, vol. 109, pp. 529-540, 2017, doi: 10.1016/j.triboint.2017.01.030

[17] Z. Tkáč, Š. Čorňák, V. Cviklovič, J. Kosiba, J. Glos, J. Jablonický, R. Bernát, Research of biodegradable fluid impacts on operation of tractor hydraulic system, Acta technologica agriculturae, vol. 20, iss. 2, pp. 42-45, 2017, doi: 10.1515/ata-2017-0008

[18] J. Kosiba, Š. Čorňák, J. Glos, J. Jablonický, V. Vozárová, A. Petrović, Monitoring oil degradation during operating tests, Agronomy Research, vol. 14, iss. 5, pp. 1626-1634, 2016.

[19] M. Bošanský, M. Vereš, J. Gaduš, Possibilities of the use of $C$-C gearings in agricultural and building machines working in environments with increased environmental hazard, Acta Technologica Agriculturae, vol. 8, iss. 3, pp. 78-81, 2005.

[20] R. Majdan, Z. Tkáč, R. Abrahám, M. Szabó, M. Halenár, M. Rášo, P. Ševčík, Proposal for filtration system for biodegradable lubricants in agricultural tractors, Agronomy Research, vol. 14, iss. 4, pp. 1395-1405, 2016.

[21] J. Padgurskas, R. Rukuiža, A. Meškinis, R. Kreivaitis, B. Spruogis, Influence of manufacturing methods on the tribological properties of rapeseed oil lubricants, Transport, vol. 31, iss. 1, pp. 56-62, 2016, doi: 10.3846/16484142.2015.1048525

[22] M. Kučera, Z. Aleš, M.Pexa, Detection and characterization of wear particles of universal tractor oil using aparticles size analyzer, Agronomy research vol. 14, iss. 4, pp. 1351-1360, 2016.

[23] J. Rieglert, Lubricating Performance of Environmnetally Adapted Hydraulic Fluids, Licentiate, $\mathrm{PhD}$ thesis, Lulea University of 
Technology, Division of Machine Elements, Lulea, 1997.

[24] A. Kabuya, J.L. Bozet, Comparative analysis of the lubricating power between a pure mineral oil and biodegradable oils of the same iso grade, Lubricants and Lubrication, vol. 30, pp. 25-30, 1995, doi: 10.1016/S0167-8922(08)70613-8

[25] M.D. Din, E. Kassfeldt, Wear characteristics with mixed lubrication conditions in a full scale journal bearing, Wear, vol. 232, iss. 2, 192-198, 1999, doi: 10.1016/S0043-1648(99)00145-3

[26] J. Ukonsaari, E. Kassfeldt, Tribological Studies on Oscillating Bronze Bearings Lubricated With Environmentally Adapted Lubricants (EALS), Journal of Tribology, vol. 128, iss. 1, pp. 181187, 2006, doi: 10.1115/TRIB2004-64136

[27] S. Ozden, F. Nair, K. Kara, Investigation of the wear behaviour of crankshaft journal bearing and bushing with respect to process parameters, Journal of the Balkan Tribological Association, vol. 17, iss. 2, pp. 192-195, 2011.

[28] J. Rusnák, M. Kadnár, F. Tóth, M. Kročko, Possibilities of using the ecological oil Arnica $S 46$ in agricultural engineering, Journal of Central European Agriculture, vol. 14, iss. 4, pp. 14611472, 2013.

[29] F. Tóth, J. Rusnák, M. Kadnár, Study of tribological properties of chosen types of environmentally friendly oils in combined friction conditions, Journal of Central European Agriculture, vol. 15, iss. 1, pp. 185-192, 2014.

[30] J. Rusnák, M. Kadnár, F. Tóth, M. Bošanský, The impact of selected environmentally friendly lubricants on the wear of the sliding bearing, Visnik Nacional'nogo techničnogo universitetu, vol. 1247, pp. 124-127, 2017.

[31] S. Baskar, G. Sriram, Tribological Behavior of Journal Bearing Material under Different Lubricants, Tribology in Industry, vol. 36, no. 2, pp. 127-133, 2014.

[32] E. Durak, H. Adatepe, A. Biyiklioglu, Experimental study of the effect of additive on the tribological properties journal bearing under running-in and start-up or shut-down stages, Industrial Lubrication and Tribology, vol. 60, iss. 3, pp. 138146, 2008, doi: 10.1108/00368790810871066

[33] T. Savașkan, G. Pürçek, S. Murphy, Sliding wear of cast zinc-based alloy bearings under static and dynamic loading conditions, Wear, vol. 252, iss. 910, pp. 693-703, 2002, doi: 10.1016/S00431648(01)00876-6

[34] H.K. Trivedi, D.V. Bhatt, Effect of lubricating oil on tribological behaviour in pin on disc test ring,
Tribology in Industry, vol. 39, no. 1, pp. 90-99, 2017, doi: 10.24874/ti.2017.39.01.10

[35] D.M.C. McCarthy, S.B. Glavatskih, Å. Byheden, Influence of oil type on the performance characteristics of a two-axial groove journal bearing, Lubrication Science, vol. 21, iss. 9, pp. 366-377, 2009, doi: 10.1002/ls.98

[36] P.G. Nikolakopoulos, D.A. Bompos, Experimental measurements of journal bearing friction using mineral, synthetic, and bio-based lubricants, Lubricants, vol. 3, iss. 2, pp. 155-163, 2015, doi: 10.3390/lubricants3020155

[37] S. Bhaumik, S.D. Pathak, A comparative experimental analysis of tribological properties between commercial mineral oil and neat castor oil using Taguchi method in boundary lubrication regime, Tribology in Industry, vol. 38, no. 1, pp. 33-44, 2016.

[38] A. Yano, E. Iwawaki, M. Mihara, S. Yoshihara, Study on the load carrying capacity of sliding bearing lubricated by synthetic ester oils, Tribology online, vol. 10, iss. 5, pp. 377-389, 2015, doi: $10.2474 /$ trol.10.377

[39] B.S. Ünlü, E. Atik, Determination of friction coefficient in journal bearings, Materials and Design, vol. 28, iss. 3, pp. 973-977, 2007, doi: 10.1016/j.matdes.2005.09.022

[40] A. Imran, H.H. Masjuki, M.A. Kalam, M. Varman, M. Hasmelidin, K.A.H. Al Mahmud, S.A. Shahir, M. Habibullah, Study of Friction and Wear Characteristic of Jatropha Oil Blended Lube Oil, Procedia Engineering, vol. 68, pp. 178-185, 2013, doi: 10.1016/j.proeng.2013.12.165

[41] S. Senhadji, F. Belarifu, F. Robbe-Valloire, Experimental investigation of friction coefficient and wear rate of brass and bronze under lubrication conditions, Tribology in Industry, vol. 38, no. 1, pp. 102-107, 2016.

[42] M. Stojilković, M. Kolb, Tribological properties of biodegradable universal tractor transmission oil, Tribology in Industry, vol. 38, no. 2, pp. 229$234,2016$.

[43] M. Kučera, J. Pršan, M. Kučera, P. Kostoláni, A systemic approach to testing the tribological properties of selected materials of agricultural machines, Journal of Central European Agriculture, vol. 15, iss. 1, pp. 146-159, 2014, doi: 10.5513/JCEA01/15.1.1426 